\title{
Mystik - et komparativt, kognitionsvidenskabeligt perspektiv
}

\author{
Torben Hammersholt Christensen
}

\begin{abstract}
ENGLISH ABSTRACT: This article is intended as a contribution to the cognitive science of religion. It analyses structural similarities in the mystical development as described by the Theravāda Buddhist monk Buddhaghosa $\left(5^{\text {th }}\right.$ century CE) and the Christian Spanish mystic Juan de la Cruz (1542-1591). The analysis shows that both descriptions culminate in a distinct type of mystical experience which I define as: A wakeful, but non-conscious and objectless experience which the mystic retrospective brings into agreement with the metaphysical centre of the particular religious classification system. This definition is supported by Antonio Damasio's cognitive and neuro-scientific theory of consciousness, and I argue that Damasio helps explain why the mystical development culminates in the defined mystical experience. With this, the article illustrates that cognitive theories have the potential to once again make topical the comparative study of religion in a post-Eliadean era by grounding cross-cultural similarities in sound theories.
\end{abstract}

DANSK RESUME: Denne artikel er intenderet som et bidrag til den religionsvidenskabelige kognitionsforskning. Den analyserer strukturelle ligheder $i$ den beskrevne mystiske udvikling hos theravādabuddhisten Buddhaghosa (5. årh. e.v.t.) og den kristne spanske mystiker Juan de la Cruz (1542-1591). Analysen viser, at begge beskrivelser kulminerer $i$ en scerlig type mystisk erfaring, som jeg definerer som: En vågen, men ikke-bevidst og objektløs erfaring, der af mystikeren retrospektivt fortolkes i overensstemmelse med det partikulcere religiøse klassifikationssystems metafysiske centrum. Definitionen får rygdoekning fra Antonio Damasios kognitive og neurovidenskabelige bevidsthedsteori, og jeg argumenterer for, at Damasio kan vare med til at forklare, hvorfor den mystiske udvikling kulminerer $i$ den definerede mystiske erfaring. Artiklen er hermed et eksempel på, at kognitive teorier kan vore med til at reaktualisere den komparative religionsvidenskab i en post-Eliade'sk cera ved at give tvarkulturelle ligheder et solidt teoretisk fundament.

KEYWORDS: Mysticism; Cognitive Science of Religion; Comparative Religion; Buddhaghosa; Juan de la Cruz.

"He who knows one knows none" sagde Max Müller i anden halvdel af det 19. århundrede, og med dette slagord ville han understrege, at det komparative aspekt er et nødvendigt udgangspunkt for et videnskabeligt studie af religion. Han betegnes ofte som grundlæggeren af den moderne religionsvidenskab (fx Sharpe 1998, 35), og det sammenlignende perspektiv har gennem fagets historie $\mathrm{i}$ vid udstrækning været dets konstituerende metode. Det gælder stadig i dag, hvor den metodiske refleksion dog rummer en del flere facetter. Dette er Religionsvidenskabens komparative udfordring (Lisdorf et al. 
2005), et særnummer af tidsskriftet Chaos, et godt eksempel på.

I det 20. århundrede var religionshistoriske sammenligninger især knyttet til den såkaldte religionsfænomenologi, en paraplybetegnelse for værker af bl.a. Rudolf Otto, Gerard Van der Leeuw og Mircea Eliade. Som Jeppe Sinding Jensen påpeger i sin disputats (2003, 30-31), i overensstemmelse med citat af Jacques Waardenburg, så var den klassiske religionsfænomenologi dog overordnet motiveret af et religiøst program med en søgen efter de værdier og den sandhed, som religionerne havde at tilbyde. Et eksempel på dette er Eliade. Ved at analysere en mangfoldighed af hierofanier fra hele verden fremtolker Eliade universelle transhistoriske strukturer, som skal udgøre en hermeneutisk referenceramme til at belyse partikulære religiøse symbolers sande mening. Problemet er, at disse strukturer - det helliges morfologi - funderes i det hellige som reel ontologisk kategori, og Eliades position er således ligeså meget et religiøst synspunkt som et videnskabeligt studie af religion. Hvor stiller det nu den komparative religionsvidenskab, hvis den indflydelsesrige fænomenologi har teoretiske og metodiske problemer? Selve grundideen med at finde strukturelle ligheder i de religiøse fænomener på tværs af traditioner er brugbar, men en analyse af strukturligheder besvarer ikke det meget centrale spørgsmål om, hvorfor sådanne eksisterer.

Siden starten af 1990'erne er der inden for religionsforskningen blevet etableret, hvad jeg vil betegne som et religionsvidenskabeligt kognitionsparadigme (RVKP), og dette prætenderer at kunne besvare førnævnte 'hvorfor'. Paradigmet udspringer af et bredt tværvidenskabeligt samarbejde kaldet 'cognitive science', hvor fokus er et studium af kognitive processer som tænkning, perception, sprog, hukommelse, indlæring, problemløsning, emotion mv. Disse mentale mekanismer er komplekse fænomener, der kan beskrives på flere niveauer, og derfor inddrages følgende fag: psykologi, neurologi, antropologi, filosofi, lingvistik og kunstig intelligens (Thagaard 2005). Førende forskere inden for det RVKP - som bl.a. antropologerne Pascal Boyer (2001) og Harvey Whitehouse (2004) - mener, at almenmenneskelige og ubevidste kognitive mekanismer kan forklare konstruktionen og transmissionen af religiøse ideer og handlinger. Religion ses her, i vid udstrækning, som et naturligt biprodukt af almen kognition.

Grundantagelserne inden for det RVKP er bestemt ikke uproblematiske, fx er der en uholdbar tendens til at nedtone den sociokulturelle konteksts indflydelse på religiøse fænomener (Sinding Jensen 2002; 2005; Sørensen 2004; Geertz 2004; 2005) - en tendens bl.a. Jeppe Sinding Jensen kalder 'kultureliminativisme'. Men på trods af denne svaghed har det RVKP også mange styrker; bl.a. har det vist, at kognitionsvidenskabelige teorier kan være med til at reaktualisere det komparative element inden for studiet af religion ved at give fundne strukturligheder et mere solidt teoretisk fundament, og at det både er muligt og relevant at operere med universelle mentale forklaringsfaktorer.

\section{Artiklens fokus}

Denne artikel vil beskæftige sig med det tværkulturelle fænomen mystik, først i Buddhaghosas (ca. 5. årh. e.v.t.) meditationsmanual Visuddhimagga (vejen til renselse), en sammenfatning af centrale doktriner inden for theravādabuddhismen, og dernæst $i$ centrale værker af den spanske kristne mystiker Juan de la Cruz (1542-1591). Ud fra et komparativt perspektiv vil strukturligheder i dette empiriske materiale blive belyst af Antonio Damasios neurovidenskabelige bevidsthedsteori (Damasio 1999). 
At opnå konsensus om en klart afgrænset definition af begrebet mystik virker ligeså umuligt som at opnå enighed om definitionen af begrebet religion. Dette er det eneste nyere danske religionshistoriske værk om fænomenet et eksempel på (Geertz; Schjødt; Jensen, alle 1990). Lad det derfor være sagt med det samme. Ingen ny, klart afgrænset og banebrydende definition af mystik vil blive fremsat her. I stedet vil jeg henlede opmærksomheden på en artikel af Jesper Sørensen (2005), "Komparation, kognition og religionsvidenskabelige prototyper”, som rummer væsentlige pointer med henblik på kategorisering. Han påpeger, at megen religionsforskning er fanget i en forældet opfattelse af kategorisering, der har rødder i den logiske positivisme. Fx er det et udbredt synspunkt, at kategorier som 'religion', 'ritual', 'bøn' og 'myte', og jeg vil tilføje 'mystik', skal være defineret gennem nødvendige og tilstrækkelige betingelser. På baggrund af George Lakoff (1987) argumenterer Jesper Sørensen for, at dette krav ikke harmonerer med, hvordan mennesket faktisk kategoriserer:

Kategorier refererer til modeller af verden, og disse modeller er lavet i bestemte sammenhænge, ud fra bestemte intentioner og med bestemte motivationer og handlinger indlejret. Samtidig opstår en struktur inden i kategorien, hvilket betyder at nogle eksemplarer anses som bedre eksempler på kategorien end andre. Dette kaldes prototype-effekten. Hermed er de [kategorierne] kendetegnet ved en vis fleksibilitet, og deres grænser er flydende (Sørensen 2005, 121).

Hvis dette er rigtigt, så er jagten på fuldstændig klart afgrænsede videnskabelige kategorier problematisk. Eller sagt med andre ord så indebærer tilgangen, at enhver definition af de kategorier vi bruger til at sammenligne med er en kort sammentrækning af de modeller, der ligger bag, og da der ofte ikke er enighed om disse, manifesterer der sig også en uenighed på definitionsniveau. Dette er et positivt aspekt, som giver faget dynamik, men det vigtige er, at det bør tilstræbes som ideal, at de bagvedliggende modeller ekspliciteres og - hvis muligt - transformeres til velfunderede teorier. Hermed understøttes kategorierne, og de får videnskabelig gyldighed og gennemsigtighed.

Jeg mener, at Jesper Sørensen påpeger noget meget væsentligt, og derfor vil denne artikels metodiske og teoretiske udgangspunkt være følgende. Buddhaghosa og Juan de la Cruz beskriver hver især en længerevarende mystisk udvikling. Hos Buddhaghosa kulminerer processen i en erfaring af nirodha-samāpatti (opnåelse af ophør) som identificeres med nibbāna (sanskrit nirvāṇa), mens kulminationen hos Juan de la Cruz kaldes erfaring af 'enhed med Gud'. 'Begge tilstande anses af de fleste forskere som gode prototyper på fænomenet mystik. En analyse af grundlæggende substantielle træk ved de forskellige religiøse klassifikationssystemer vil danne udgangspunkt for en komparativ analyse af strukturligheder. Denne viser, at begge systemer kulminerer i en scerlig type mystisk erfaring. En tilstand, som jeg vil definere som en vågen, men ikke-bevidst og objektløs erfaring, der af mystikeren retrospektivt udlægges i overensstemmelse med det partikulære religiøse klassifikationssystems metafysiske centrum (i dette tilfælde henholdsvis nibbāna og Gud). Definitionen henter mening og videnskabelig rygdækning fra neurologen Antonio Damasios bevidsthedsteori, og det er min grundlæggende opfattelse, at teorien kan forklare naturen af den objektløse erfaring samt de fundne struktur-

${ }^{1}$ Da jeg i denne artikel fokuserer på theravādabuddhismen, hvis tekster er skrevet på pāli, vil alle buddhistiske udtryk herefter blive gengivet på pāli. Enkelte begreber vil også, hvor det skønnes at lette forståelsen, blive gengivet på sanskrit, fx nibbāna (sanskrit nirvāṇa). 
ligheder i den mystiske udvikling. Det er vigtigt at understrege, at definitionen på ingen måde prætenderer at udtømme kategorien mystik, men blot at indkredse en særlig (proto)type af begrebet. Det skal her også nævnes, at Armin Geertz (2004, 364-65; 2005, 15-16) og Ilkka Pyysiäinen (2001, 114-120) begge foreslår, at Antonio Damasios bevidsthedsteori er frugtbar for religionsvidenskaben. Pyysiäinen mener endda, at Damasio "provides a sound basis for a general framework for studying mysticism" (2001, 115). Nærværende artikel tager således disse opfordringer op.

\section{Fænomenet mystik - et forskningshistorisk perspektiv}

En af de mest indflydelsesrige personer inden for den nyere mystikforskning er Steven Katz (1978; 1983; 1992). Antologien Mysticism and philosophical analysis fra 1978, som han har redigeret, står som et skelsættende og centralt værk, hvor bidragene afspejler et opgør med den tidligere forskning. Dette formuleres særligt klart i Katz' eget essay. Her kritiserer han bl.a. følgende forestilling: Mystiske erfaringer kan inddeles i en begrænset tværkulturel typologi, hvor de enkelte typer af erfaringer er de samme på tværs af religiøse traditioner, men da mystikerne er bundet af den socio-religiøse kontekst, er fortolkningerne forskellige. To markante fortalere for dette synspunkt er Zaehner (fx 1961) og Stace (fx 1961).

Foruden åbenlyse økumeniske og apologetiske motiver lider den tidligere forskning, ifølge Katz, især af én fejl, nemlig en manglende anerkendelse af forskelle, og essayet er grundlæggende "a plea for the recognition of differences" $(1978,25)$. En grundig analyse af kilderne viser, at de tværkulturelle typologier er for reduktive og ufleksible. Der er tværtimod ligeså mange typer af mystiske erfaringer, som der er inkorporerede fortolkninger af dem. Det vil sige, at ikke blot mystikerens fortolkning er bundet af det partikulære socio-religiøse klassifikationssystem, men denne kontekst determinerer også selve erfaringen. Denne markante 'kontekstualisme' og 'konstruktivisme' bygger på en ekstrem epistemologisk antagelse, nemlig at "There are NO pure (i.e. unmediated) experiences":

A proper evaluation of this fact leads to the recognition that in order to understand mysticism it is not just a question of studying the reports of the mystic after the experiential event but of acknowledging that the experience itself as well as the form in which it is reported is shaped by concepts which the mystic brings to, and which shape, his experience $(1978,26)$.

Hvis religiøse klassifikationssystemer determinerer den religiøse erfaring, så er enhver snak om ensartede tværkulturelle erfaringer naturligvis problematisk, da religiøse kontekster er forskellige.

I antologien The Problem of Pure Consciousness (1990) skriver bogens redaktør, Robert K. C. Forman: “Katz's essay has so forcefully stated this position that it has become virtually the received view of the eighties on mysticism." (1990, 9). Han har derfor taget initiativ til bogen, hvori der udtrykkes en grundlæggende kritik af Katz' position, som han mener er funderet i en "profoundly ill-established thesis, argued more by rhetoric than philosophy" (1990, preface). Med rette påpeger Forman, at Katz begår en cirkelslutning. Efter den førnævnte epistemologiske tese er fremført, skriver Katz, at resten af artiklen vil levere evidens for dette synspunkt, men som Forman udtrykker det: "the remaining thirty-nine pages of the article provides virtually no further argumentati- 
on but only instances of this assumption" (1990, s. 16). Fx gennemgår Katz fra side 3339 forskellene mellem buddhistiske og jødiske doktriner, hvorefter han konkluderer, at det er umuligt at ligestille erfaringen af 'nirvana' (af Katz kaldet en erfaring af 'ikkeselv' og rolig 'tomhed') og 'devekuth' (af Katz kaldet en erfaring af et intenst og intimt kærlighedsforhold mellem to substantielle selv'er: det menneskelige selv og en personlig Gud) på dette grundlag. Forman påpeger her, at en sådan opremsning af forskelle kun leverer bevis for erfaringens kontekstafhængighed, hvis den nødvendige kausale forbindelse mellem det partikulære klassifikationssystem og erfaringen forudscettes. Katz giver blot eksemplificeringer på en allerede antaget ekstrem epistemologisk påstand.

På baggrund af ovenstående konkluderer Forman, at Katz ikke overbevisende har vist, at rene umedierede erfaringer ikke eksisterer. De er en logisk mulighed, og han finder direkte empirisk belæg for dem i kilderne. Forman peger i den forbindelse på en særlig erfaring, som han kalder for en 'pure consciousness event' (PCE), og denne defineres som "a wakeful though contentless (non-intentional) consciousness" $(1990,8)$. Det er denne særlige mystiske bevidsthedstilstand, som underbygger hans forestilling om en tværkulturel 'common core', en ensartet erfaring. Første del af antologien indeholder fire artikler, som analyserer empirisk materiale fra forskellige traditioner - bl.a. beskriver Forman selv Eckharts (1260-1327) mystik - og han mener, at det her etableres som et faktum, uden for enhver rimelig tvivl, at rapporter om PCE's eksisterer. En vurdering, som også Pyysiäinen er enig i $(1993,46)$. I bogen Mystical Experience and Religious Doctrine (1982) konkluderer filosoffen Philip Almond ligeledes efter en grundig kritisk analyse af de forskellige forskningspositioner: "There is nothing logically incoherent about the notion of a contentless experience" (s. 174). Og også han finder det plausibelt, at kildematerialet indeholder eksempler på sådanne indholdsløse erfaringer (s. 174-80).

Med henblik på denne artikels fokus er diskussionen for og imod muligheden af indholdsløse (non-intentionale) erfaringer meget relevant. Personligt mener jeg, at Katz på fremragende vis har bragt forskningen videre ved at fokusere på forskelle samt understrege den socio-religiøse konteksts markante indflydelse både på mystiske erfaringer og fortolkninger. Jeg er dog enig i Formans ovenstående kritik. Empirien viser, at rapporter om indholdsløse/objektløse erfaringer eksisterer, hvilket mine analyser af Juan de la Cruz' og Buddhaghosas skrifter ligeledes understøtter. Forman ville sikkert kalde de analyserede eksempler for PCE's, men i forlængelse af Antonio Damasios bevidsthedsteori vil jeg argumentere for, at disse objektløse erfaringer er vågne, men ikke bevidste tilstande. Når det specifikt gælder denne type mystisk erfaring, er jeg fortaler for en kognitiv 'common core' tilgang, hvor den ensartede fælles kerne af erfaringer ikke er funderet $i$ en påstået transempirisk virkelighed, men i det menneskelige sind. Argumentet får teoretisk rygdækning og videnskabelig gyldighed ved at henvise til en kognitiv realitet, der er almenmenneskelig qua mennesket som homo sapiens.

\section{Theravādabuddhisme: Buddhaghosas Visuddhimagga}

Bhadantācariya Buddhaghosa var en theravādabuddhistisk munk, som kom til Sri Lanka fra Indien i det 5. århundrede e.v.t. Her arbejdede han på kommentarværker til Palikanon (Tipitaka), der sandsynligvis blev nedskrevet samme sted omkring det 1 . århundrede f.v.t. Det var også her, han forfattede sit mest indflydelsesrige værk, Visuddhimag- 
$g a$ (vejen til renselse). ${ }^{2}$ Her gennemgås den vej, som skal følges for at bryde ud af genfødslernes evige cyklus (samsā̄ra). Målet er nibbāna: begærets (tanhā) og uvidenhedens (avijjā) udslukkelse, lidelsens (dukkha) ophør. Det monumentale værk, der er på 905 sider i engelsk oversættelse, er af Buddhaghosa intenderet som en loyal sammenfatning af Siddhattha Gotamas lære, som den udtrykkes i Pali-kanon. Det er samtidig en meget udførlig og detaljeret meditationsmanual, der har haft en enorm indflydelse på udviklingen af den theravādabuddhistiske ortodoksi.

Ideelt set går vejen til nibbāna over en udvikling af tre delmomenter, og derfor er $\mathrm{Vi}$ suddhimagga overordnet inddelt i tre dele. For det første, hvilket er helt fundamentalt, skal man leve et moralsk dydigt liv (sīla) (I-II). For det andet skal man udvikle koncentration (samādhi), hvilket sker meditativt gennem mental sindsro (samatha) (III-XIII), og for det tredje skal man udvikle visdom (pañ̃̃a) med henblik på at se tingene inden for samsāra, som de virkelig er: impermanente (anicca), lidelsesfulde (dukkha) og selvløse (anattā) (XIV-XXIII). En sådan visdom er nært knyttet til indsigt (vipassanā), der udvikles meditativt gennem opmærksomhed (sati). I Vism.s sidste og kulminerende kapitel (XXIII) beskrives en række fordele ved at udvikle visdom. Her understreges det, at det kun er ved at kombinere vipassanā og samatha, at erfaringen nirodha-samapātti (opnåelse af ophør) realiseres, og denne identificeres med nibbāna.

Denne struktur kræver i udgangspunktet et par kommentarer. Samatha og vipassanā udtrykker i grunden to forskellige meditative teknikker. I samatha fokuseres sindet fuldstændigt i ét punkt, meditationsobjektet, og alle sanseindtryk lukkes ude. Dette fører til en form for dyb klar trance, hvorefter bevidstheden progressivt tømmes for indre mentalt indhold. Vipassanā er mere analytisk og intellektuelt undersøgende og udtrykker en opmærksom iagttagelse af fx fysiske og mentale fænomener, hvorved de erfaringsmæssigt erkendes som selv-løse, impermanente og utilfredsstillende. Der eksisterer en åbenlys soteriologisk spænding mellem disse to teknikker som Vism. forsøger at nedtone for at inkorporere dem i én sammenhæng. Hvilken teknik har forrang på vejen til oplysning? Hvordan skal de kombineres? Ifølge Winston King (1980) udspringer samatha-teknikken af en fælles indisk 'brahmansk-yogisk' baggrund, som overtages af den tidlige buddhisme, hvorimod vipassanā udgør et mere originalt buddhistisk element. Paul Griffths foreslår, at de to teknikker er forbundet med to forskellige soteriologiske mål (1987, 13-17). Ifølge én strømning er det grundlæggende menneskelige problem 'begær', en uholdbar tilknytning til fænomenerne inden for saṃsāra. Målet er her at frigøre sig fra dette begær, hvilket sker gennem samatha, hvor bevidstheden tømmes for ethvert indhold, der kan mediere en tilknytning til verden. Ifølge den anden strømning er det grundlæggende menneskelige problem 'uvidenhed', en manglende indsigt i hvordan de samsariske fænomener virkelig er. Målet er her at opnå en sådan visdom, hvilket sker gennem vipassanā, hvor fænomenerne erkendes som impermanente, selv-løse og lidelsesfulde. Griffiths foreslår ligeledes, at de buddhistiske intellektuelle hurtigt fik gjort det til ortodoksi, at den rette soteriologiske metode med nødvendighed måtte indebære analytiske momenter (ibid., 23). Derfor blev dét kanoniske materiale, som syntes at rumme en sammenhængende soteriologisk metode uafhængig af vipassanā, forsøgt indpasset under denne ortodoksi. Hos Buddhaghosa er dette veletableret, og han er

\footnotetext{
${ }^{2}$ Visuddhimagga forkortes Vism., og henvisninger følger skemaet: kapitel, afsnit (fx XXIII, 18). Med mindre andet er nævnt, er alle henvisninger i dette afsnit til Vism.
} 
således påpasselig med at beskrive nirodha-samāpatti, den naturlige kulmination på samatha-teknikken, under overskriften: "Fordele ved visdommen" (XXIII). Samtidig understreger han, at en kombination af både samatha og vipassanā er en nødvendig forudsætning for denne erfaring.

Med sådanne overvejelser melder der sig straks et centralt spørgsmål. Har Buddhaghosa i sin systematisering udlagt de kanoniske skrifter 'korrekt', i overensstemmelse med deres intention? Dette spørgsmål er interessant, men det har en så stor rækkevidde, at det ikke kan diskuteres her. Jeg vil blot fremhæve at identifikationen af nirodha-samapātti med nibbāna også findes i Pali-kanon (jf. fx Griffiths 1981; 1987; Schmithausen 1981; Vetter 1988; Bronkhorst 1993). ${ }^{3}$ Et mere relevant spørgsmål i denne sammenhæng omhandler forholdet mellem tekst og erfaring. Er nirodha-samāpatti ikke blot en ideologisk/skolastisk konstruktion, hvor det er umuligt at slutte til en bagvedliggende, reel erfaring? Dette mener fx Robert Sharf (1995). Der er helt sikkert en høj grad af skolastisk konstruktion på spil hos Buddhaghosa, men helt at ignorere et distinkt erfaringsaspekt bag nirodha-samāpatti er efter min opfattelse en for skeptisk metodisk tilgang. Det vil jeg argumentere for senere efter gennemgangen af min empiri. Her vil jeg fortsætte analysen med fokus på samatha, da nirodha-samāpatti falder i naturlig forlængelse af udviklingen inden for denne teknik.

Hvad er nu koncentration (samādhi)? "It is the centering of consciousness and consciousness-concomitants evenly and rightly on a single object” (III, 3). Buddhaghosa nævner fyrre meditationsobjekter, der gennemgås i Vism.s anden del (III, 104). Et eksempel (jf. IV). En munk arrangerer et konkret udtryk for den fysiske materie (kasina), det kan være en skive af jord, som han placerer foran sig på et uforstyrret sted i klosteret. Herefter fæstnes blikket på jordskiven, og han koncentrerer sig om det mentale genbillede (nimitta). Ordene 'jord, jord' gentages, skiftevis med øjnene åbne og lukkede, og når der opstår et mentalt genbillede, der kan fastholdes uafhængigt af det fysiske meditationsobjekt, er 'indlæringstegnet' (uggaha-nimitta) opnået (IV, 30). Dette lykkes måske først efter mere end tusind forsøg. Ved at modarbejde de fem forhindringer sansebegær, ond vilje, sløvhed, uro og tvivl (IV, 104-105) kan indlæringstegnet udvikles yderligere og forvandles til et 'imitationsgenbillede' (pațibhāga-nimitta), der er “thousand times more purified" (IV, 31), en helt ren mental form uden jordskivens urenheder. Dette beskrives som ekstremt svært at opnå, men lykkes det, realiseres en meditativ tilstand, der benævnes 'adgangskoncentration' (upacāra-samādhi) (IV 32-33). Denne er adgangen til en fuldstændig absorption, hvor enhver form for sanseindtryk er udelukket, og det er her den egentlige meditation, jhāna (sanskrit dhyāna), er opnået. Overgangen fra adgangskoncentration til jhāna er resultatet af en udvikling af fem jhāna-faktorer (IV, 106-108): den målrettede tanke (vitakka), den undersøgende tanke (vicāra), lyksalighed (pīti), glæde (sukha) og sindets samling i ét punkt (cittass' ekaggatā). Jhāna kan

\footnotetext{
${ }^{3}$ Peter Harvey er uenig i denne vurdering (1995, 187-88). For en kritik af Harveys synspunkt se evt. mit speciale som afleveres til bedømmelse d. 1/3 2007. Det kan herefter lånes via biblioteket på Syddansk Universitet Odense, eller man kan få det tilsendt ved at kontakte mig via mail (adresse jf. sidst i artiklen). Specialet har titlen: "Fra neuronen til nibbāna. En religionsvidenskabelig analyse af soteriologiske veje og mål inden for den tidlige buddhisme med inddragelse af Antonio Damasios neurologiske bevidsthedsteori”. I øvrigt er Harveys forestilling om nibbāna som en 'objektløs erfaring', hvor personlighedsgrupperne (khandha'erne) stopper, meget interessant for det forskningsprogram, som jeg senere vil foreslå, og som mit speciale forsøger at indfri (Harvey 1995, kap. 11-12).
} 
således karakteriseres som en form for dyb trance, men en særlig bevidst trance, hvor bevidstheden er meget mere klar, rolig og fokuseret, end det er tilfældet med den almindelige hverdagsbevidsthed.

Der eksisterer fire jhāna-stadier (IV, 79-202), også kaldet fire sfærer af 'fin materie' ( rüpāvacara). Fin materie har her intet med grov fysisk materie at gøre, men transcenderer denne, og begrebet 'materie' (rüpa) bruges bl.a. fordi, meditationsobjektets mentale væren er et genbillede af et fysisk objekt og besidder form. Koncentrationen på imitationsgenbilledets rene mentale form, kaldet kasina-materialiteten, udvikles i disse fire stadier til perfektion. Det første og laveste jhāna-stadie er kendetegnet ved de fem jhāna-faktorer. Efterhånden som udviklingen skrider frem, udvikles visse jhāna-faktorer yderligere, mens andre ophører. Dette kulminerer midlertidigt i det fjerde jhāna-stadie, hvor kun den sidstnævnte jhāna-faktor, sindets samling i ét punkt, er tilbage, mens de fire andre er transcenderet til fordel for en subtil neutral følelse af sindsligevægt (upekkhā).

Men også det fjerde jhāna-stadie kan transcenderes, fordi:

although he has already surmounted gross physical matter by means of the fourth jhana of the fine material sphere, nevertheless he still wants also to surmount the kasina materiality since it is the counterpart of the former $(\mathrm{X}, 2)$.

Ved at transcendere kasiṇa-materialiteten træder den mediterende ind på vejen med de fire immaterielle/formløse stadier (āruppa-nidessa) (X). Her 'fjernes' kasiṇa-materialiteten ved ikke at give den nogen form for opmærksomhed, og sindets fokus, meditationsobjektet, bliver det uendelige formløse rum, der træder i dets sted, og den mediterende absorberes således i det første immaterielle stadie kaldet 'det uendelige rum' (X, 1-24). Denne tilstand transcenderes ved koncentration på den 'grænseløse bevidsthed' (X, 25 31), der dækker det uendelige rum, og den grænseløse bevidsthed transcenderes selv ved fokus på 'intethed' (X, 32-39). Udviklingen kulminerer foreløbigt i tilstanden 'hverken-perception-eller-ikke-perception' (X, 40-55). Denne beskrives som en ekstrem subtil og paradoksal tilstand, hvor perception, følelse og bevidsthed er så 'svag', at tilstanden ikke kan tilskrives disse egenskaber, men samtidig er der en eller anden form for 'rest' tilbage, så der er heller ikke tale om ikke-perception, ikke-bevidsthed og ikkefølelse (X, 49-54).

Kan denne ekstremt subtile tilstand transcenderes? Ja, der gives en endelig og ultimativ absorption, hvor den beskrevne proces, der tydeligvis arbejder hen mod et totalt ophør af enhver form for perception, tanke og følelse, kulminerer: nirodha-samāpatti (XXIII, 16-52):

What is the attainment of cessation [nirodha-samāpatti]? It is the non-occurrence of consciousness and its concomitants owing to their progressive cessation (XXIII, 18).

Let us dwell in bliss by being without consciousness here and now and reaching the cessation that is nibbana (XXIII, 30). "dwell in bliss" betyder her 'uden lidelse', jf. note 13 til tekstpassagen

Buddhaghosa beskriver her en ikke-bevidst objektløs erfaring, der identificeres med nibbāna. Den adskiller sig kun fra døden ved at "life is unexhausted... heat has not subsided" (XXIII, 51), og dette svarer nogenlunde til processerne inden for det autonome centrale nervesystem (Griffiths 1990, 79-80). 
Fra et sekulært perspektiv er det tydeligt, at fortolkningen af nirodha-samāpatti som nibbāna, i kraft af tilstandens ikke-bevidste natur, er en retrospektiv udlægning. Men selve erfaringen er ikke determineret af den sociale kontekst, som Katz mener. Der er ikke noget indhold at forme. Nirodha-samāpatti er derimod resultatet af en meditativ teknik, der i princippet ikke er afhængig af partikulært sprog, religiøst klassifikationssystem eller anden social kontekst.

\section{Kristen mystik: Juan de la Cruz}

Den spanske mystiker Juan de la Cruz (1542-1591) personificerer kulminationen på den blomstrende spiritualitet, der kendetegner Spanien i det 16. århundrede. På opfordring af hans nære bekendte Teresa de Jesus (1515-1582) indtræder han i $1568 \mathrm{i}$ den reformerede karmelitterorden, og det er i de efterfølgende årtier, 1570'erne og 1580'erne, at han skriver sine mystiske hovedværker. Følgende analyse bygger på tre af disse: Subida del Monte Carmelo (Bestigningen af Bjerget Karmel, skrevet 1582-84), Noche Oscura del Alma (Sjælens mørke nat, skrevet 1582-84) og Cántico Espirituel (Åndelig sang, endelig revideret udgave færdiggjort i 1586). ${ }^{4}$ Alle tre er prosaiske kommentarværker, der tager udgangspunkt i digte, hvor Juan de la Cruz (JC) i metaforisk stil beskriver den vej, man må gå for at opnå den fuldkomne forening med Gud. Han udvikler flere forskellige metaforer for denne vej, og disse inddeles typisk i tre faser. Fx sammenlignes den mystiske vandring med det at gennemleve en nat (især S; N) - skumring, midnat og morgengry - og det er denne metafor, som min analyse vil fokusere på. Men først nogle kommentarer til den grundlæggende antropologi og teologi.

Før JC gik ind i den barskoede karmelitterorden, studerede han i fire år på universitetet i Salamanca. Her stiftede han bekendtskab med skolastisk filosofi, bl.a. Thomas Aquinas, der syntetiserer Aristoteles og katolicismen. Dette afspejler sig i JC's forfatterskab. Han påpeger, at skrifterne udspringer af egne mystiske erfaringer, men han er samtidig påpasselig med at understrege overensstemmelsen mellem disse erfaringer og den kristne kanon/tradition, hvorfor han flittigt benytter sig af implicitte og eksplicitte bibelcitater samt skolastisk teologi (C: Prolog; S: prolog, 2). Overordnet fremhæver han den filosofiske forestilling om, at to modsætninger ikke kan eksistere i samme subjekt (jf. Aquinas/Aristoteles). Dette har fundamental betydning, da JC ser en markant ontologisk differens mellem det uskabte, evige og ubetingede (Gud) på den ene side og det skabte, endelige og betingede på den anden. Hvis det menneskelige subjekt, nærmere bestemt dets sjæl, vil forenes med Gud, må der således skabes en vis lighed mellem de to, hvilket vil sige, at menneskets sjæl må transformeres, så det bliver Gud lig (S: 1.4,2 / 1.6,1-2 / 2.16,7). Enhver tilknytning til det skabte og verdslige må forkastes. Hvad dette indebærer, skal ses i forlængelse af JC's antropologi (C: XVI, 10-11).

Sjælen inddeles grundlæggende i en sanselig del og en åndelig del. Den sanselige del inddeles igen i en række ydre sanser (syn, hørelse, smag, lugt og følesans) og to indre sanser (fantasi og forestillingsevne), mens den åndelige del omfatter fakulteterne

\footnotetext{
${ }^{4}$ Subida del Monte Carmello forkortes herefter S og henvisninger til dette værk følger skemaet: bog. kapitel, afsnit (fx S: 2.1,3). Noche Oscura del Alma forkortes N, og henvisninger følger skemaet: bog. kapitel, afsnit (fx N: 2.1,2). Cántico Espiritual forkortes C, og henvisninger følger skemaet: vers, kommentarafsnit til vers (fx C: XXII,3). Alle værkerne er læst i oversættelse (for referencer se 'kilder' under litteraturlisten), og det er herfra, at de citerede passager i dette afsnit stammer.
} 
fornuft, hukommelse og vilje. I overensstemmelse med Aquinas mener JC, at sjælen ved fødslen er en tabula rasa, og enhver form for naturlig viden bygger ultimativt på sanseerfaring (S: 2.3,2). Målet er nu at frigøre sig fra denne naturlige/verdslige viden knyttet til det skabte og vende tilbage til en sjælelig tabula rasa tilstand (S: 1.3,1-6; Mark 2000, 150-52). Dette skal forstås på to niveauer. For det første hentydes til konkret meditativ praksis, hvor forudsætningen for de mest udviklede mystiske erfaringer af enhed med Gud er, at de sjælelige led $i$ disse bevidsthedstilstande er i fuldstændig ro, altså helt konkret renskrevne. For det andet afstedkommer sådanne erfaringer at mennesket, uden for disse tilstande, lever i en form for paradisisk tabula rasa tilstand af uskyld (jf. Adam før syndefaldet), hvor det selvfølgelig sanser og tænker, men ikke på nogen måde begærer det sansede, det skabte, de naturlige forestillinger mv. Dette er en mere overordnet renskrevethed.

Ovenstående udtrykker ligeledes en bevægelse fra naturlig til overnaturlig viden. Mennesket tømmes for den naturlige/verdslige viden, hvorefter det, i de mystiske erfaringer af enhed, modtager overnaturlig visdom. Dette forhold formuleres kort og præcist af Birgitta Mark: "the mind is like a container that can be filled up with content and emptied again thereby enabling a refilling with more attractive content" $(2000,170)$. Dette skal uddybes.

Vejen til forening med Gud beskriver JC som det at gennemleve en nat. Den første del er mørkets frembrud, skumringen, hvor den sanselige del af sjælen formørkes, og den kaldes derfor også 'sansernes nat' (S: 1.4-15). Her må begæret efter sansegenstande tilintetgøres, da "de mennesker, der retter deres begær efter noget skabt, [er] lige så langt borte fra Gud som det skabte, de begærer" (S: 1.5,1). På det overordnede niveau betyder dette, at mennesket skal løsrive sig fra begær efter god mad, rigdom, fine klæder mv. På niveauet for meditative øvelser, som jeg fra nu af vil fokusere på, betyder det, i JC's terminologi, en overgang fra meditation til kontemplation. Meditation er for begyndere, som endnu ikke er trådt ind i natten. Den er en aktiv fokuseret øvelse, hvor man i koncentration og indre fordybelse mediterer over fx bibelske hændelser eller forestillingsbilleder som Jesus på korset. Kontemplationen er derimod total passiv. Målet er at få alle sjælens evner til at være i fuldstændig ro, jf. førnævnte tabula rasa-tilstand (S: 2.12-15).

I sansernes nat, der kan vare flere år, starter den kontemplative praksis, men på dette niveau er den langt fra perfekt: "the purgation of sense is only the entrance and beginning of contemplation" ( $\mathrm{N}: 2.2,1)$. I overensstemmelse med metaforen opøves her evnen til at opnå bevidsthedstilstande, hvor den sanselige del af sjælen - sanseindtryk og forestillingsbilleder - formørkes, altså udelukkes fra bevidstheden. Sjælen oplever her mange følelser og indsigter, som kommer fra Gud og som giver store glæder, men "the communications that are granted to these souls cannot be very strong or very intense or very spiritual, as is required for Divine union with God" $(\mathrm{N}: 2.1,2)$. Vil sjælen udvikle perfekt kontemplation, må også enhver tilknytning til sådanne kommunikationer ophøre. Dette sker ved at gennemleve nattens mørkeste del (midnatten), hvor også den åndelige del af mennesket - fornuft, vilje og erindring - formørkes, og derfor kaldes denne del for 'åndens nat' (S: 2-3). Teologisk formuleres processen gennem begreberne tro, håb og kærlighed: "Troen skaber tomrum i intelligensen og lægger dens forståelse i mørke. Håbet tømmer erindringen for dens indhold. Kærligheden gør viljen tom og blotter den for dens higen og trang til alt, hvad der ikke er af Gud" (S: 2.6,2). Forestillingerne om 
tro og tomhed i fornuften er her helt centrale. Enhver tanke eller forestilling, som mennesket selv kan fostre om Gud, eller andre ting, er en forhindring i at opnå unio mystica. Den ontologiske differens mellem skaber og skabning kan kun transcenderes, hvis alle sådanne opgives i tro, og derfor er tro $\mathrm{i}$ bogstaveligste forstand identisk med tomhed $\mathrm{i}$ fornuften.

Ud over naturlige tanker er det i åndens nat også altafgørende at frigøre sig fra såkaldte overnaturlige tanker, der kommer til fornuften (S: 2,10). Sådanne er enten sansede eller åndelige. De sansede omfatter visioner af fx engle og helgener (S: 2.11) og overnaturlige forestillingsbilleder (S: 2.16). De åndelige er enten tydelige eller dunkle. De tydelige modtages gennem såkaldte åndelige sanser udenom de fysiske sanser og fornuftens aktive medvirken (S: 2.23,1-4). JC kalder dem for: åndelige følelser, åndelige syner, åndelige åbenbaringer og åndelige hørlige budskaber (S: 2.23-32). For disse, og alle førnævnte overnaturlige tanker, gælder, at de kan komme fra Gud, men de kan også komme fra Djævelen, og da det er svært at kende afsenderen med sikkerhed, er det bedst at frigøre sig totalt fra dem alle. De er en forhindring for den højeste kontemplative forening med Gud (S: 2.23,4). Målet er i stedet den dunkle åndelige viden. Dunkel fordi fornuften ikke fatter den: "Den dunkle og altomfattende viden er enestående; det er den kontemplation, der kommer fra troen" (S: 2.10,4). Hvad er nu dette for en viden?

Når den kontemplative teknik mestres, skabes der en sjælelig tabula rasa tilstand, hvor alle sjælens naturlige evner ophører. Denne erfaring beskrives således:

This divine interior exercise also requires withdrawal and detachment from all things, whether from the lower part of man, which is that of the senses, or from the higher part, which is that of the reason, in the which two parts are comprised the entire harmony of the faculties and senses of a man ... no representation or form of any object that pertains to any of these faculties or senses whereof we have spoken may appear ... In all the spiritual faculties of the soul - namely the understanding, the memory and the will - let there be no other knowledge or private affections or considerations of any kind; and in all the senses and faculties of the body, both inward and outward, such as the imagination [forestillingsevnen], the fancy [fantasien], etc., and seeing, hearing, etc., let there be no other digressions and forms, and images and figures, neither representations of objects to the soul, nor other natural operations (C: XVI,10-12).

Hvis sjælen opnår denne tilstand, hvor der hverken er (naturlige) sanseindtryk, følelser eller tanker, er det muligt at Gud, som en nådegave, vil forene sig fuldt og helt med sjælen. Dette kaldes i Cántico Espirituel for det åndelige bryllup, og dette er den højeste tilstand, som er mulig i dette liv (C: XXII, 3). Midnatten er her forbi, og lyset (Gud) begynder at stråle frem (jf. daggry). I forlængelse af denne artikels problemformulering er det interessante spørgsmål nu, om der her er tale om en objektløs erfaring? Brylluppet karakteriseres således:

[There] is effected such union of the two natures and such communication of the Divine nature to the human, that, while neither of them changes its being, each of them appears to be God...it surpasses everything that can be described or conceived (C: XXII,4).

I kraft af sagens uudsigelige natur fortæller JC ikke meget om, hvad foreningen og den overnaturlige (dunkle) visdom konkret indebærer. Det påstås dog, at en eller anden form for viden kommunikeres, og spørgsmålet er, om man ud fra en sekulær religionsvidenskabelig optik, hvor man ikke kan bruge en transcendent realitet eller transcendent erfa- 
ring som forklaringsfaktor, må sige at erfaringen udtrykker en vis naturlig intentionalitet, selvom JC skriver, at alle sjælens naturlige evner er i fuldstændig ro? I den forbindelse er der en passage, som jeg finder særligt oplysende:

Når sjælen således træder ind i Guds nærhed, kommer den dunkle, kærlighedsfulde viden om Gud - en tilstand fuld af fred og ro, hvor sjælen drikker visdom, kærlighed og sødme ...Man må lægge mærke til, at den ubestemmelige forståelse, vi taler om, til tider er så fin og skrøbelig - især når den er helt ren, enkel og fuldkommen, og når den tillige er åndelig og dyb - at sjælen slet ikke opfatter den, skønt den er nedsænket i den ... Jo mere ren, fuldkommen og enkel sjælen er, desto mindre evner forstanden at fatte af denne tilstand, og desto dunklere forekommer den ... Sjælen [befinder] sig i en slags ekstase. Den ved ikke, hvor den har været, eller hvad den har gjort, og den har ikke følt tiden gå. Det kan hænde, at denne ekstase varer mange timer, og når sjælen finder sig selv igen, forekommer det som et øjeblik eller som slet ingen ting. Forståelsen gennemtrænger sjælen, gør den enkel, ren og lutret for alle sansernes og erindringernes tanker og former og sænker derved sjælen i glemsel og tidløshed ... sjælen har været forenet med Gud i den rene tanke uden for tiden ... Når sjælen vender tilbage til sin normale tilstand, bevarer den de frugter, som lyset [Gud] såede, uden at sjælen har set dem vokse frem; sindet var jo hævet til himmelsk tanke, frigjort fra alt, uden billeder og minder ... Den rene overnaturlige viden har ikke altid ekstase til følge. Glemslen opstår kun, når Gud fratager brugen af alle naturlige og åndelige evner. Det sker ret sjældent, for denne viden tager som regel ikke sjælen helt i besiddelse (S: 2.14,2-12).

Denne beskrivelse er ikke at finde i forbindelse med det åndelig bryllup, men der er ingen tvivl om, at der også her er tale om en fuldt udviklet kontemplativ erfaring i nattens tredje fase (morgengry). I denne dybe ekstatiske erfaring opstår der glemsel og tidløshed, og sjælen ved ikke, hvor den har været, eller hvad der er sket. Fra et sekulært perspektiv udlægger jeg klart denne erfaring som objektløs - uden nogen form for sansning, følelse eller tænkning. Det interessante i denne passage er, at den giver et indblik i forholdet mellem selve erfaringen og JCs kristne retorik. Der er tydeligvis tale om en retrospektiv udlægning. Der står direkte, at sjælen har været i total glemsel uden tidsfornemmelse, men dette fortolkes efterfølgende som forening med Gud og kommunikation af guddommelig visdom (i forlængelse heraf er det ikke overraskende, at en sådan viden karakteriseres som dunkel!). Det er således muligt, at når $\mathrm{JC}$ taler om den mest fuldkomne forening med Gud og kommunikation af overnaturlig visdom, er der også her tale om samme retrospektive udlægning. Hermed mener jeg ikke, at det nødvendigvis er alle af JCs mest udviklede mystiske erfaringer, der er objektløse, men blot at nogle helt klart er. Derfor er jeg uenig med Birgitta Mark, der skriver, at ingen af JCs mystiske erfaringer er indholdsløse (2000. 236.277). JC er langt fra lige så detaljeret og teknisk i de meditative beskrivelser som Buddhaghosa, men følgende overordnede struktur træder alligevel klart frem. Først internaliseres bevidstheden i meditativ koncentration, hvorefter den kontemplativt langsomt tømmes for indhold. Dette resulterer i visse tilfælde i en objektløs erfaring, som fortolkes retrospektivt i overensstemmelse med den kristne traditions metafysiske centrum, Gud.

Antonio Damasios neurologiske bevidsthedsteori

En af verdens førende og mest anerkendte neurologer er Antonio Damasio. Han er portogisisk født, men arbejder i USA. I bogen The feeling of what happens-body, emotion 
and the making of consciousness (1999) fremsætter han en teori om, hvad bevidsthed er, og hvordan den konstrueres i den menneskelige hjerne. Det overordnede, originale og provokerende synspunkt er, at bevidsthed er tæt knyttet til emotion, og evolutionsbiologisk har begge udviklet sig, fordi de var nyttige mekanismer for den menneskelige organismes (kroppens) overlevelse. I tilknytning hertil argumenterer Damasio for, på baggrund af studier af forskellige læsioner i hjernen og de korrelerede konsekvenser for mentalt liv og adfærd, at den menneskelige bevidsthed ikke er nogen monolit, men grundlæggende kan opdeles i simpel kernebevidsthed (med kerneselv) og en mere kompleks udvidet bevidsthed (med selvbiografisk selv). Ligeledes kan bevidsthed og vågen tilstand, såvel som bevidsthed og sprog, adskilles. Det er bevidsthedens sammensatte natur, samt dens mulige adskillelse fra vågen tilstand, der har særlig relevans i denne sammenhæng, og som derfor er fokus i dette afsnit.

At beskæftige sig med det neurale grundlag for bevidsthed indebærer to grundlæggende problemer, som Damasio påpeger er nært forbundne (s. 8-12. 317-323). ${ }^{5}$ Det første omhandler det kausale forhold mellem mentale billeder og neurale mønstre. Hvad er forholdet mellem det velkendte mentale billede af $\mathrm{fx}$ en bil, og de neurale processer i hjernen som korrelerer med denne perception? Hvordan 'opstår' det private mentale billede af det neurale mønster? Damasio anerkender, at neurovidenskaben ikke har løst dette problem, men mener, at det med tiden sandsynligvis vil blive muligt at overkomme den eksisterende forklaringskløft: "There is a gap to be filled by not yet identified but presumably identifiable physical phenomena" (s. 323). At opretholde et analytisk skel mellem mentale billeder og neurale mønstre, i stedet for blot at tale om neurale mønstre i hjernen, er således "a simple matter of intellectual hygiene, and...not the result of dualism" (s. 323). Filosofisk set udlægger jeg dette som en uafklaret, ontologisk materialisme. ${ }^{6}$ Dette er relevant at eksplicitere, da denne uafklarede materialisme dermed også kommer til at ligge bagved min teoretiske brug af begrebet mystik, jf. mine indledende overvejelser over kategorisering.

For Damasio er mentale billeder repræsentationer af objekter. Begrebet 'objekt' bruges i meget bred betydning og kan fx være en ting, et sted, en relation, en melodi, en smerte som tandpine og emotionelle tilstande som fx lyksalighed, men udtrykket dækker også enhver form for erindring. Fælles for alle mentale billeder er, at de grundlæggende er opbygget af de visuelle, auditive, gustatoriske, olfaktoriske og somatosensoriske sansemodaliteter - 'somatosensorisk' henviser her til 'kropssansning' i bred betydning. Den kontinuerlige strøm af mentale billeder kalder Damasio for sind (eng. 'mind'), og metaforisk sammenlignes sindet med en film-i-hjernen. Denne 'filmstrimmel' vælger han at betegne tcenkning, og den kører hele tiden, mens vi er vågne, og mens vi drømmer - normalt kun afbrudt af dyb drømmeløs søvn - så "one might argue that images are the currency of our minds" (s. 319). Men sind er ikke det samme som bevidsthed (eng. 'consciousness'). Bevidstheden oplyser kun en del af den kontinuerlige strøm af sindbilleder, mens en stor del af sindets mekanismer opererer ikke-bevidst.

Dette fører frem til det andet bevidsthedsproblem, som omhandler den selvfornemmelse, der uløseligt knytter sig til alle bevidste mentale billeder. Når jeg ser på min

\footnotetext{
${ }^{5}$ Alle sidehenvisninger i dette afsnit er til: Antonio Damasio, The feeling of what happens, 1999.

${ }^{6}$ For en (filosofisk) diskussion af materialismens uafklarede status se fx Søren Harnow Klausen (2003) og Erich Klawonn (2001).
} 
computerskærm, konstrueres et mentalt billede, men sideløbende konstrueres også en klar fornemmelse af selv. Det er mig, og ikke en anden der perciperer. I overensstemmelse med den tidligere metafor er problemet at forklare den mekanisme, som genererer fornemmelsen af, at der én som ser og ejer filmen-i-hjernen. Damasios bog er kort sagt et forsøg på at diskutere bevidsthedsforhindringen med direkte fokus på dette selvproblem, og da enhver bevidsthed er 'bevidsthed med en fornemmelse af selv', er der tale om en diskussion af bevidstheden generelt.

Det er Damasios centrale overbevisning, at udgangspunktet for en mulig løsning på problemet er at betragte bevidsthed ud fra to aktører, organismen (kroppen) og objektet, samt relationen mellem dem (s. 19-31. 133-167):

The neural patterns and images necessary for consciousness to occur are those which constitute proxies for the organism, for the object, and for the relationship between the two. Placed in this framework, understanding the biology of consciousness becomes a matter of discovering how the brain can map both the two players and the relationships they hold (s. 20).

Organismen repræsenteres i hjernen af en samling neurale mønstre, som hvert eneste øjeblik kortlægger tilstanden af kroppens fysiske strukturer i dens mange dimensioner, og disse bevarer organismen inden for rammerne af de grænseværdier, der er en forudsætning for at overleve. Damasio kalder dem for protoselvet, da han her finder selvbevidsthedens biologiske forløber. Vi er os altså ikke dette protoselv bevidst. Objektet, hvad enten det er aktuelt perciperet eller erindret, kortlægges i hjernen i de sensoriske og motoriske områder.

Både organismen og objektet kortlægges som neurale mønstre i hjernen i såkaldte førsteordens kort. Disse kan blive til mentale billeder i sindet, men bevidsthed opstår først når:

the brain's representation devices generate an imaged, nonverbal account of how the organism's own state is affected by the organism's processing of an object, and when this process enhances the image of the causative object, thus placing it saliently in a spatial and temporal context (s. 169).

De sensomotoriske kort over objektet påvirker organismens tilstand, hvorved protoselvet forandres. Disse forandringer kan re-repræsenteres i andenordens kort, som dermed repræsenterer relationen mellem krop og objekt. Andenordens kort kan i lige så høj grad som førsteordens kort blive til mentale billeder, men førstnævnte er ensbetydende med selvbevidsthedens fødsel, hvilket Damasio udtrykker med begrebet kerneselv. De mentale billeder, som kerneselvet udgør, er en tavs, nonverbal billedfortælling, der er uløseligt forbundet med objektbillederne:

The wordless narrative I propose is based on neural patterns which become images, images being the same fundamental currency in which the description of the consciousnesscausing object is also carried out. Most importantly, the images that constitute this narrative are incorporated in the stream of thoughts. The images in the consciousness narrative flow like shadows along with the images of the object for which they are providing an unwitting, unsolicited comment. To come back to the metaphor of movie-in-the-brain, they are within the movie. There is no external spectator (s. 171). 
Kerneselvet er således en flygtig størrelse, der opstår i kraft af kroppens forandring som resultat af organismens interaktion med et objekt, og dette gentages uophørligt i forbindelse med hvert eneste objekt, som hjernen repræsenterer. Intet objekt, ingen (selv)bevidsthed! Den form for bevidsthed der knytter sig til kerneselvet, kalder Damasio for kernebevidsthed. Det er her vigtigt at understrege, at kernebevidstheden ikke afhænger af hverken konventionel hukommelse, arbejdshukommelse, logisk tænkning eller sprog, og den er heller ikke kun karakteristisk for mennesker. Kernebevidsthed er et simpelt biologisk fænomen, der er stabil i hele organismens levetid, og som kun har ét organisationsniveau. Damasio ser den som skabt i pulsslag, hvor hvert pulsslag udløses af interaktionen med et nyt objekt, og heraf udspringer bevidsthedens kontinuitet:

In healthy individuals, as long as the brain is awake, the machines of image making and consciousness are "on", and we are not manipulating our mental state by doing something like meditation, it is not possible to run out of "actual" objects or "thought" objects, and it is thus not possible to run out of the abundant commodity called core consciousness. There are just too many objects, actual or recalled, and often there is more than one object at about the same time (s. 170-171) [kursivering tilføjet].

Kernebevidsthedens omfang er begrænset til det aktuelle her og nu. Den giver organismen selvfornemmelse af ét øjeblik, nuet, og ét sted, her, men giver ingen bevidsthed om fortid, fremtid og personlig identitet. Dette kræver udvidet bevidsthed, hvortil der knytter sig et selvbiografisk selv (s. 195-233). Både i den individuelle og evolutionære udvikling er det arbejdshukommelsen og den konventionelle hukommelse, der muliggør dette skridt. Erindringer om organismens tidligere erfaringer (selvbiografisk hukommelse) skaber et forholdsvist stabilt arkiv, der muliggør et selvbiografisk selv, en personlig identitet, hvor erfaringer er forbundet med en fortid og en forventet fremtid. Men det er vigtigt at påpege, at den grundlæggende bevidsthedspuls stadig er den samme:

Autobiographical memories are objects, and the brain treats them as such, allows each of them to relate to the organism in the manner described for core consciousness, and thus allows each of them to generate a pulse of core consciousness, a sense of self knowing (s. 196-197).

Hermed bliver kernebevidsthed forudsætningen for udvidet bevidsthed. Dette viser sig bl.a. ved, at neuropatologiske skader i hjerneområder der knytter sig til kernebevidsthed også kompromitterer den udvidede bevidsthed, hvorimod det omvendte ikke er tilfældet. Damasio påpeger, at også ikke-humane væsener som fx aber og hunde har udvidet bevidsthed, men hos mennesket er denne udviklet i særlig grad. Her forstærkes den yderligere af sproget, og den har muliggjort fænomener som kompleks logisk tænkning, kreativitet, samvittighed mv.

Der er desværre ikke plads til at gengive Damasios meget interessante neuropatologiske eksempler, der underbygger hans teori. Som en fin skalpel dissekerer de bevidsthedens lag. Han giver mange detaljerede eksempler på patienter, hvor enten den udvidede bevidsthed eller både kernebevidsthed og udvidet bevidsthed er skadet. Disse ledsages af en grundig argumentation for, hvordan protoselv, kernebevidsthed og udvidet bevidsthed korrelerer med bestemte strukturer i hjernen og samtidig udtrykker forskellige evolutionære trin. Her skal det blot nævnes, at epileptisk automatisme, abcenser og akinetisk mutisme er eksempler på tilstande, hvor kernebevidsthed, og dermed også udvidet bevidsthed, er sat ud af funktion (s. 94-106). Men patienten er stadig vågen og 
opretholder visse elementære aspekter af et sind. Under den ikke-bevidste tilstand af epileptisk automatisme kan personen fx drikke af en kop, rejse sig fra sin stol og bevæge sig rundt. Efter et lille stykke tid kommer vedkommende til bevidsthed igen og husker intet fra selve anfaldet.

I ovenstående citat skrev Damasio, at en rask vågen person - der ikke dyrker meditation! - ikke løber tør for erkendelsesobjekter og dermed bevidsthed. Denne indskudte sætning om meditation, i øvrigt det eneste sted i hele bogen Damasio nævner meditation, er her særlig interessant, da den viser, at han er åben overfor muligheden af en meditativ erfaring, der manipulerer med kernebevidsthedsmekanismen. Det ligger i citatet/teorien, at hvis der ikke er nogle objekter, ophører "the abundant commodity called core consiousness". Jeg vil netop foreslå, at de meditative teknikker hos Buddhaghosa og Juan de la Cruz tømmer bevidstheden for objekter, hvorved bevidstheden 'slukkes', og der opnås en objektløs og ikke-bevidst, men vågen sindstilstand/erfaring. ${ }^{7}$ Damasios neuropatologiske eksempler viser, at det neurale grundlag er til stede for at skelne mellem en vågen og en bevidst tilstand. Hermed siger jeg ikke, at den mystiske erfaring er direkte sammenlignelig med sådanne patologiske tilstande. Sidstnævnte er fremkommet på grund af skader i hjerneområder, der understøtter kernebevidsthedsmekanismen, hvorimod meditationen skaber en anormal erfaring ved at manipulere en ellers rask og veletableret kernebevidsthedsmekanisme.

\footnotetext{
${ }^{7}$ Det følger af Damasios teori, at en erfaring ikke altid er en bevidst erfaring, da der skelnes mellem sind og bevidsthed. I forlængelse af hans teori vil jeg derfor definere erfaring bredt som: Alle sindstilstande som organismen gennemlever i tid.
} 
Skema: overordnede strukturer i den mystiske udvikling ${ }^{8}$

\begin{tabular}{|c|c|c|c|c|}
\hline $\begin{array}{l}\text { Mystisk } \\
\text { udvikling }\end{array}$ & $\begin{array}{l}\text { Theravāda / } \\
\text { Visuddhimagga }\end{array}$ & Juan de la Cruz & $\begin{array}{l}\text { Overordnede } \\
\text { strukturligheder }\end{array}$ & $\begin{array}{l}\text { Antonio Dama- } \\
\text { sios bevidstheds- } \\
\text { teori }\end{array}$ \\
\hline Fase 1 & $\begin{array}{l}\begin{array}{l}\text { Koncentrations- } \\
\text { øvelser } \\
\text { Sindets fokuse- } \\
\text { ring i ét punkt }\end{array} \\
\text { Jord-kasiṇa } \\
\text { Indlæringstegn } \\
\text { Imitationsgen- } \\
\text { billede / } \\
\text { Adgangskon- } \\
\text { centration } \\
\text { Mystisk teknik: } \\
\text { samatha }\end{array}$ & $\begin{array}{l}\text { Koncentrations- } \\
\text { øvelser } \\
\text { Indre fordybelse } \\
\text { over kristne dok- } \\
\text { triner og fore- } \\
\text { stillingsbilleder } \\
\text { Mystisk teknik: } \\
\text { meditation }\end{array}$ & $\begin{array}{l}\text { Meditativt udeluk- } \\
\text { kes sanseindtryk } \\
\text { efterhånden fra } \\
\text { bevidstheden } \\
\text { Tilbagetrækning til } \\
\text { et ensomt og roligt } \\
\text { sted } \\
\text { Meget tidskræven- } \\
\text { de }\end{array}$ & $\begin{array}{l}\text { Progressiv ude- } \\
\text { lukkelse af ydre } \\
\text { sanseobjekter fra } \\
\text { det bevidste sind }\end{array}$ \\
\hline Fase 2 & $\begin{array}{l}\text { De fire jhāna- } \\
\text { stadier } \\
\text { De fire imma- } \\
\text { terielle stadier } \\
\text { Mystisk teknik: } \\
\text { samatha }\end{array}$ & $\begin{array}{l}\text { Åndens mørke } \\
\text { nat (midnat) } \\
\text { Fornuft, erin- } \\
\text { dring og vilje } \\
\text { formørkes } \\
\text { Mystisk teknik: } \\
\text { Kontemplation }\end{array}$ & $\begin{array}{l}\text { Meditativt tømmes } \\
\text { bevidstheden helt } \\
\text { for objekter } \\
\text { Ensomt og roligt } \\
\text { sted } \\
\text { Meget tidskræ- } \\
\text { vende }\end{array}$ & $\begin{array}{l}\text { Ydre sanse- } \\
\text { objekter ude- } \\
\text { lukket fra be- } \\
\text { vidstheden } \\
\text { Progressiv ude- } \\
\text { lukkelse af indre } \\
\text { tankeobjekter fra } \\
\text { det bevidste sind }\end{array}$ \\
\hline Fase 3 & $\begin{array}{l}\text { Nirodha- } \\
\text { samāpatti } \\
\text { Erfaring af } \\
\text { nibbāna }\end{array}$ & $\begin{array}{l}\begin{array}{l}\text { Enhed med Gud } \\
\text { (morgengry) }\end{array} \\
\text { Sjælen fyldes } \\
\text { med overnatur- } \\
\text { lig, uudsigelig og } \\
\text { dunkel visdom }\end{array}$ & $\begin{array}{l}\text { En objektløs erfa- } \\
\text { ring tolkes retro- } \\
\text { spektivt i overens- } \\
\text { stemmelse med det } \\
\text { partikulære rel- } \\
\text { igiøse klassifika- } \\
\text { tionssystems meta- } \\
\text { fysiske centrum }\end{array}$ & $\begin{array}{l}\text { Bevidstheds- } \\
\text { pulsen er ophørt } \\
\begin{array}{l}\text { Ingen kerne- } \\
\text { bevidsthed }\end{array} \\
\begin{array}{l}\text { Ingen udvidet } \\
\text { bevidsthed }\end{array} \\
\text { Vågen tilstand }\end{array}$ \\
\hline
\end{tabular}

\footnotetext{
${ }^{8}$ Det skal understreges, at skemaet er tiltænkt som en oversigt, der kun fremhæver forhold, som er særligt relevante for denne artikels problemformulering. Inddelingen i de forskellige faser mv. er således blot et analytisk redskab til at tydeliggøre centrale pointer.
} 
Metodisk mellemregning - kan man slutte fra 'tekst' til 'erfaring'?

Inden jeg begynder på den komparative analyse af strukturligheder og uddyber ovenstående skema, er det nødvendigt med en metodisk overvejelse. Er det muligt at slutte fra en mystisk tekst til en bagvedliggende erfaring? I to meget interessante og provokerende artikler fremlægger Robert Sharf $(1995 ; 2001)$ det synspunkt, at "the emphasis on meditative experience as the sine qua non of Buddhism is misplaced" (1995, 233). Han argumenterer bl.a. for, at det er et problem, at forskere ser ideologiske præskriptioner som distinkte, fænomenologiske beskrivelser. Fx har "the notion of nirodha [samāpatti] all the makings of a wholly scholastic construct" $(1995,237)$. Han benægter ikke, at visse personer kan opleve noget, men centrale begreber har ingen fælles fænomenologisk referent. Begreber som upacāra-samādhi, jhāna, nirodha-samāpatti, vipassanā mv. skal nærmere ses som ideologiske og polemiske konstruktioner (ibid., 260), og den buddhistiske meditationsretorik er i høj grad et forsøg på legitimering og opretholdelse af autoritet og magt (ibid., 265). På denne baggrund giver det ingen mening at slutte fra tekst til erfaring.

Der er ingen tvivl om, at både Pali-kanon og Vism. indeholder skolastiske konstruktioner, men selvom Sharf fremhæver mange gode pointer, så er hans tilgang til mystiske erfaringer efter min mening en tand for kritisk. Når det gælder den særlige mystiske erfaring, som er fokus for denne opgave, vil jeg argumentere for, at der i det buddhistiske kildemateriale og hos Juan de la Cruz er belæg for at slutte fra tekst til erfaring. Primært af to grunde. For det første: Strukturligheder i den mystiske udvikling fra forskellige traditioner giver empirisk belæg for, at der faktisk eksisterer en potentiel objektløs erfaring, og at begreber som nirodha-samāpatti og 'enhed med Gud' dermed ikke blot er tomme ideologiske eller skolastiske konstruktioner, men refererer til en reel erfaring. For det andet: Antonio Damasio leverer teoretisk belæg for at operere med en objektløs, men ikke-bevidst og vågen erfaring, der er funderet i en almenmenneskelig kognitiv 'common core'.

\section{Komparativ analyse og applikation af kognitiv teori}

I skemaet har jeg valgt at inddele den mystiske udvikling, der beskrives af Buddhaghosa (Bg.) og Juan de la Cruz (JC) i tre faser. Der er selvfølgelig store indbyrdes forskelle mellem de to forløb, men alligevel er der nogle overordnede strukturligheder, der træder klart frem. Første fase er kendetegnet ved en gradvis udvikling af meditative tilstande, hvor sanseindtryk udelukkes totalt fra bevidstheden. Bg. beskriver, hvordan sindet gennem koncentration (samādhi) og sindsro (samatha) fokuseres i ét punkt, meditationsobjektet. Gennem meget omfattende øvelser, hvor indlæringstegnet forvandles til et imitationsgenbillede og adgangskoncentration opnås, forstærkes denne koncentration gradvist. Når der ikke længere er rastløshed eller begær efter nogen sanselige indtryk, og tankerne ikke flakker rundt, men er fuldstændig fokuseret $i$ ét punkt - jf. overvindelsen af de fem forhindringer og udvikling af jhāna-faktorerne - opnås en klar indre trancetilstand (jhāna), hvor enhver form for sanseindtryk er udelukket fra bevidstheden. Overgangen fra adgangskoncentration til jhāna er derfor baggrunden for mit analytiske skel mellem fase et og fase to.

Hos JC er første fase inddelt i to. I første del praktiserer begynderne det, som beteg- 
nes meditation. I indre fordybelse fokuseres bevidstheden på kristne doktriner og forestillingsbilleder. Anden dels begyndelse er det tidspunkt, hvor den egentlige mystiske udvikling starter. Her går mystikeren ind i natten, og nu benyttes en helt anden meditativ teknik, nemlig kontemplationen. Her er sjælsevnerne, ideelt set, fuldstændig passive, men på dette stadie, sansernes nat, er det dog især sjælens nederste sanselige del (sanseindtryk og forestillingsbilleder), der skal bringes i ro. Det er svært at afgøre, om der her er lige så dybe bevidsthedstilstande, som beskrives af Bg. på dette niveau, men det er helt sikkert, at ved slutningen af sansernes nat, ved overgangen til åndens nat, beskriver JC dybe bevidsthedstilstande, hvor alle sanseindtryk er helt udelukket, og derfor er der her et analytisk skel mellem fase et og fase to.

Anden fase er karakteriseret ved at bevidstheden gradvist tømmes for indre indhold. Bg. beskriver her de fire jhāna-stadier og de fire immaterielle stadier. Det kan ikke udelukkes, at der med de mere subtile inddelinger er tale om skolastisk konstruktion uden fænomenologisk referent, men den overordnede proces er klar. Der sker en gradvis reduktion af enhver tænkeevne, følelse og perception. Dette er resultatet af, at det mentale meditationsobjekt, imitationsgenbilledet, først transcenderes af det immaterielle niveau og herefter gradvist reduceres til ingenting.

Hos JC er anden fase kendetegnet ved en udvikling af kontemplativ perfektion, hvor alle sjælelige evner er i fuldstændig ro (jf. tabula rasa). I åndens nat skal forstanden, viljen og erindringen frigøre sig fra alle naturlige objekter, og også visse overnaturlige tanker er i denne periode vigtige at afvise. Hvordan den kontemplative færdighed opøves, rent teknisk, beskrives ikke i detaljer, men det er tydeligt, at målet er at tømme bevidstheden for alle perceptioner, tanker og følelser, ligesom det var tilfældet for anden fase hos Bg.

Tredje fase er karakteriseret ved, at den mystiske udvikling kulminerer i en objektløs erfaring, der retrospektivt tolkes i overensstemmelse med den religiøse traditions metafysiske centrum. Af Bg. kaldes denne for nirodha-samāpatti, og erfaringen udlægges retrospektivt som nibbāna. Hos JC beskrives den objektløse erfaring som sjælsevnernes totale kontemplative ro, og tilstanden udlægges retrospektivt som enhed med Gud og kommunikation af overnaturlig, uudsigelig og dunkel visdom.

Det er interessant at bemærke, at der også findes en strukturlighed i motivationen for at opnå en sådan erfaring. I theravādabuddhismen eksisterer der en markant dikotomi mellem fænomenerne inden for saṃsāra på den ene side og nibbāna på den anden, og målet er at frigøre sig fra enhver tilknytning til samsariske fænomener. Hos JC eksisterer en markant dikotomi mellem det skabte på den ene side og Gud på den anden, og målet er at frigøre sig fra enhver tilknytning til det skabte. Selvom klassifikationssystemerne er forskellige, tilstræber de i verdslig realitet det samme: en transcendering af alle perceptioner, følelser og tanker (der henholdsvis repræsenterer tilknytning til 'saṃsāra' og 'det skabte').

Den beskrevne mystiske udvikling hos Bg. og JC kan sættes på følgende overordnede strukturelle formel: Sanseindtryk udelukkes, og bevidstheden tømmes for indre mentalt indhold, hvilket kulminerer i en objektløs erfaring. Denne formel er interessant at sammenholde med Damasios neurovidenskabelige bevidsthedsteori. Først sker der en progressiv udelukkelse af ydre sanseobjekter fra det bevidste sind, jf. fase et, og derefter begynder en progressiv udelukkelse af indre tankeobjekter fra det bevidste sind, jf. fase to. Det mest interessante aspekt er, hvad der ifølge Damasios teori sker, når repræsenta- 
tionen af objekter totalt ophører. Al (selv)bevidsthed, fra dens mest simple form til de mest komplicerede former, er afhængig af kernebevidsthedsmekanismen. Forudsætningen for denne mekanisme er på den ene side en repræsentation af organismen (protoselvet) og på den anden side en repræsentation af objektet, og bevidstheden opstår, når der skabes et andenordenskort, der re-repræsenterer, at organismen er blevet forandret af et objekt. De meget tidskrævende meditative teknikker afstedkommer, at enhver repræsentation af objekter ophører, og dermed sker der det, som Damasio skriver normalt ikke sker (for vågne raske mennesker, der ikke dyrker meditation), nemlig at bevidstheden løber tør for erkendelsesobjekter. Uden objekter ophører bevidsthedspulsen (kernebevidstheden), og da denne mekanisme er forudsætningen for al bevidsthed, falder hele bevidsthedens bygningsværk - fra simpel kernebevidsthed til kompleks udvidet bevidsthed - fra hinanden. Dermed opstår der i tredje fase en objektløs erfaring, og på baggrund af Damasios skelnen mellem vågen og bevidst tilstand, vil jeg foreslå, at det er en ikke-bevidst, men vågen sindstilstand. Dette kan være med til at forklare, hvorfor teksterne klart adskiller erfaringen fra enhver form for søvn (hvor den dybe drømmeløse tilstand også er objektløs og dermed uden bevidsthed).

Damasios teori rummer også interessante perspektiver med hensyn til specifikke forskningshistoriske problemstillinger inden for de partikulære religiøse traditioner, $\mathrm{fx}$ den tidlige buddhisme. ${ }^{9}$ I den forbindelse er det interessant nærmere at undersøge den mulige oprindelse til de omdiskuterede begreber 'nibbāna' og 'anattā' (sanskrit anātman). Med hensyn til førstnævnte skriver Winston King:

Perhaps even aboriginally, the yogic experience of a timeless, utterly detached, trancic peace was an important ingredient and determinant of the Buddhist conception of Nibbana: that is, it is an experience-produced doctrine (1980, preface).

På baggrund af Damasios teori finder jeg dette plausibelt. Religionshistorisk kan man påpege, at begrebet nibbāna - med den etymologiske betydning af enten at puste en flamme ud eller forhindre flammen $i$ at brænde ved at fjerne dens brændstof (Keown, 2003, s. 196) - er polemisk vendt mod de vediske ildoffer-ritualer, og at anattādoktrinen er en markering overfor Upanishadernes forestilling om et substantielt jeg (sanskrit ātman). Men hvorfor netop reagere mod disse strømninger i den indiske tradition på denne særlige buddhistiske måde? Er der kun tale om socio-kulturelle forklaringsfaktorer? Jeg vil foreslå følgende som et potentielt forskningsprogram. Måske vil en analyse af teksterne til den tidlige buddhisme sandsynliggøre, at Buddhas oprindelige erfaring af nibbāna netop var en objektløs erfaring, og at denne har haft en stor betydning for konstruktionen af det buddhistiske klassifikationssystem. En sådan erfaring transcenderer netop personlighedsgrupperne (khandha'erne) - materiel form (rüpa), følelse (vedanā), apperception (sañ̃̄ā), viljesimpuls (saìkhāra) og bevidsthed (viñ̄̄anna) - og dette har måske fostret den opfattelse, at der i og bag khandha'erne ikke er noget substantielt permanent jeg. Måske har erfaringen været med til at skabe den klare dikotomi mellem nibbāna på den ene side og de velkendte fænomener inden for saṃsāra på

\footnotetext{
${ }^{9}$ Med 'tidlig buddhisme' mener jeg de tidligste lag i Pali-kanon og refererer til den tekstgruppe, som Harvey kalder for 'early Suttas' (1995, 9-11). Dette materiale "is not specifically 'Theravādin', but is simply the collection of teachings that this school happened to preserve from among the early, non-secterian body of teachings." (ibid., 9).
} 
den anden. Khandha'erne er uløseligt forbundet med saṃsāra og dukkha og genstand for mange fænomenologiske beskrivelser og klassifikationer (i filosofisk, ikke religionsfænomenologisk, forstand). Den jeg-løse erfaring af nibbāna må derimod, i kraft af sin ikke-bevidste og objektløse natur, nødvendigvis være uudsigelig og ubeskrivelig, hvorfor den ofte indkredses gennem negationer. ${ }^{10}$

Disse antydninger viser, at en kognitiv teori som Damasios rummer et stort potentiale til fremtidig forskning, da teorien giver incitament og teoretisk rygdækning til at tolke bestemte kilder på en særlig måde. Det virker naturligt, at empirisk funderede bevidsthedsmodeller kan bruges i analysen af kildemateriale, hvor meditative bevidsthedstilstande spiller en altafgørende rolle - ikke for at afvikle traditionelle tilgange, slet ikke, men som et interessant supplement til disse.

\section{Konklusion}

Denne artikel er tænkt som et bidrag til den religionsvidenskabelige kognitionsforskning. Den har vist, at det er muligt at operere med universelle kognitive forklaringsfaktorer inden for religionsforskningen, og at kognitionsvidenskaben har potentiale til at være med til at re-aktualisere den komparative religionsvidenskab i en post-Eliade'sk æra. Når det gælder en særlig (proto)type af fænomenet mystik, vidner kilder fra theravādabuddhismen og Juan de la Cruz om overordnede strukturligheder i den mystiske udvikling. En proces, der kulminerer i en objektløs, men ikke-bevidst og vågen erfaring, der retrospektivt udlægges i overensstemmelse med traditionens metafysiske centrum. Dette argument henter teoretisk rygdækning fra Antonio Damasios neurovidenskabelige bevidsthedsteori. Endvidere har jeg eksemplificeret potentialet i Damasios teori ved at foreslå, at den kan danne udgangspunkt for et forskningsprogram, der undersøger i hvilken grad den mystiske objektløse erfaring har været doktrinær matrix for begreber som 'nibbāna' og 'anattā' samt andre centrale forestillinger inden for den tidlige buddhisme.

Endelig er artiklen en opfordring til, at religionsforskere, i deres iver efter at distancere sig fra den klassiske religionsfænomenologis fokusering på irreducible erfaringer, ikke nægter kategorien 'religiøs erfaring' en central plads i det religionsvidenskabelige vokabular. Mystiske erfaringer er ikke en irreducibel sui generis kategori (jf. Otto/ Eliade), men en kategori, der bestemt er åben for kognitiv religionsvidenskabelig teoridannelse.

\footnotetext{
${ }^{10}$ Se evt. mit speciale hvor jeg forfølger dele af dette forskningsprogram, jf. note 3.
} 


\section{Litteratur}

ALmond, PhiLIP

1982 Mystical Experience and Religious Doctrine. An Investigation of the Study of Mysticism in World Religions, Berlin, Mouton Publishers.

BOYER, PASCAL

2002 Religion Explained. The Human Instincts that Fashion Gods, Spirits and Ancestors, London, Vintage, 2001.

BRONKHORST, JOHANNES

1993 The Two Traditions of Meditation in Ancient India, Delhi, Mortilal Banarsidass.

DAMASIO, ANTONIO

2000 The Feeling of What Happens. Body, Emotion and the Making of Consciousness, London, Vintage, 1999.

FORMAN, ROBERT K. C.

1990 "Introduction: Mysticism, Constructivism, and Forgetting", in: Robert K. C. Forman, ed., The Problem of Pure Consciousness. Mysticism and Philosophy, Oxford University Press, New York, 3-49.

1998 "Introduction: Mystical Consciousness, the Innate Capacity, and the Perennial Philosophy", in: Robert K. C. Forman, ed., The Innate Capacity. Mysticism, Psychology, and Philosophy, Oxford University Press, New York.

GEERTZ, ARMIN W.

1990a "Introduktion: Mystik som et religionsvidenskabeligt problemområde", in: Per Bilde \& Armin W. Geertz, eds., Mystik-Den indre vej? En religionshistorisk udfordring, Aarhus Universitetsforlag, Århus, 9-32.

1990b “Mystik, visioner, ekstase og besættelse: En direkte linie?”, in: Per Bilde \& Armin W. Geertz, eds., Mystik - Den indre vej? En religionshistorisk udfordring, Aarhus Universitetsforlag, Århus, 107-138.

2004 "Cognitive Approaches to the Study of Religion", in: Peter Antes, Armin W. Geertz \& Randi R. Warne, eds., New Approaches to the Study of Religion, Walter de Gruyter, Berlin, 347-99.

2005 “Om religion og kognition”, Religionsvidenskabeligt Tidsskrift 46, 5-26.

GIMELLO, ROBERT

1978 "Mysticism and Meditation", in: Steven T. Katz, ed., Mysticism and Philosophical analysis, Sheldon Press, London, 170-199.

1983 "Mysticism in Its Context", in: Steven T. Katz, ed., Mysticism and Religious Traditions, Oxford University Press, Oxford, 61-88.

GOMBRICH, RICHARD

2004 Theravadabuddhism. A Social History From Ancient Benares to Modern Colombo, Routledge, London, 1988.

GRIFFITHS, PAUL J.

1981 "Concentration or Insight: The Problematic of Theravāda Buddhist MeditationTheory", The Journal of the American Academy of Religion 49, 605-24.

1987 On Being Mindless. Buddhist Meditation and the Mind-body Problem, Open Court Publishing Company, Illinois, 1986.

1990 "Pure Consciousness and Indian Buddhism", in: Robert K. C. Forman, ed., The Problem of Pure Consciousness. Mysticism and Philosophy, Oxford University Press, New York, 71-97. 
HARVEY, PETER

1990 An Introduction to Buddhism. Teachings, History and Practices, Cambridge University Press, Cambridge.

1995 The Selfless Mind. Personality, Consciousness and Nirvana in Early Buddhism, RoutledgeCurzon, London.

JENSEN, JEPPE SINDING

1990 “Mystikken som rituelt sprog”, in: Per Bilde \& Armin W. Geertz, eds., Mystik-Den indre vej? En religionshistorisk udfordring, Aarhus Universitetsforlag, Århus, 155-170.

2002 "The Complex Worlds of Religion: Connecting Cultural and Cognitive Analysis", in: Ilkka Pyysiäinen \& Veiko Anttonen, eds., Current Approaches in the Cognitive Science of Religion, Continuum, London, 203-25.

2003 The Study of Religion in a New Key. Theoretical and Philosophical Soundings in the Comparative and General Study of Religion, Aarhus Universitetsforlag, Århus.

2005 "Kognition og betydning", Religionsvidenskabeligt Tidsskrift 46, 63-76.

KATZ, STEVEn T.

1978 "Language, Epistemology, and Mysticism", in: Steven T. Katz, ed., Mysticism and Philosophical analysis, Sheldon Press, London, 22-74.

1983 "The 'Conservative' Character of Mystical Experience", in: Steven T. Katz., ed., Mysticism and Religious Traditions. Oxford University Press, Oxford, 3-60.

1992 "Mystical Speech and Mystical Meaning", in: Steven T. Katz, ed., Mysticism and Language, Oxford University Press, New York, 3-41.

KeOWN, DAMIEN

2004 Oxford Dictionary of Buddhism, Oxford University Press, New York, 2003.

KING, WINSTON L.

1980 Theravada Meditation. The Buddhist Transformation of Yoga, Mortilal Banarsidass Publishers, Delhi.

KLAusen, Søren Harnow

2003 "Efter reduktionismen", in: Dan Zahavi \& Gerd Christensen, eds., Subjektivitet og videnskab. Bevidsthedsforskning i det 21. århundrede, Roskilde Universitetsforlag, Frederiksberg, 13-38.

KLAWONN, ERICH

2001 Sjcel-legeme-problemet. Positioner og argumenter, Odense Universitetsforlag, Odense.

LAKOFF, GEORGE

1987 Women, Fire, and Dangerous Things: What Categories Reveal about the mind, University of Chicago Press, London.

LiSDORF, ANDERS ET AL., ed.

2005 Religionsvidenskabens komparative udfordring, Museum Tusculanums Forlag, København.

MARK, BIRGITTA

2000 Mysticism and Cognition. The Cognitive Development of John of the Cross as Revealed in his Works, Aarhus Universitetsforlag, Århus.

Pind, Ole Holten

2005 Buddhismen. Tekster fra theravada-traditionen, Systime Academic, Viborg.

PYYSIÄINEN, ILKKA

1993 Beyond Language and Reason. Mysticism in Indian Buddhism, Suomalainen Tiedeakatemia, Helsinki.

2001 How Religion Works. Towards a New Cognitive Science of Religion, Brill, Leiden. 
SCHJøDT, JENS PETER

1990 "Mystikken og Den anden Verden. Et essay om problemerne ved en indplacering af mystik som en religionsfænomenologisk kategori”, in: Per Bilde \& Armin W. Geertz, eds., Mystik - Den indre vej? En religionshistorisk udfordring, Aarhus Universitetsforlag, Århus, 139-154.

SCHMITHAUSEN, LAMBERT

1981 "On some Aspects of Descriptions or Theories of Liberating Insight and Enlightenment in Early Buddhism”, in: Klaus Bruhn \& Albrecht Wezler, eds., Studien zum Jainismus und Buddhismus, Franz Steiner Verlag, Wiesbaden, 199-250.

SHARF, ROBERT

1995 "Buddhist Modernism and the Rhetoric of Meditative Experience", in: Numen. International Review for the History of Religions 42, 3, 228-283.

2000 "The Rhetoric of Experience and the Study of Religion", in: Jensine Andresen \& Robert K. C. Forman, eds., Cognitive Models and Spiritual Maps, Imprint Academic, Thorverton, 267-287.

SHARPE, ERICH J.

1998 Comparative Religion. A History, Second Edition. London, Duckworth.

Stace, Walter T.

1961 Mysticism and Philosophy, London, Macmillian.

SøRENSEN, JESPER

2004 "Religion, Evolution and an Immunology of Cultural Systems", in: Evolution and Cognition 10, 1, 61-73.

2005 "Komparation, kognition og religionsvidenskabelige prototyper (eller hvorfor man sammenligner æbler og pærer)", in: Haviv Joel, Anders Lisdorf, \& Peter Weiss Poulsen, eds., Religionsvidenskabens komparative udfordring, Museum Tusculanums Forlag, København, 111-126.

THAGAARD, PAUL

2005 Mind. Introduction to Cognitive Science, 2. ed,. MIT Press, Cambridge.

VETTER, TILMANN

1988 The Ideas and Meditative Practises of Early Buddhism, Leiden, E.J. Brill.

WhiteHOUSE, HARVEY

2004 Modes of Religiosity: A cognitive Theory of Religious Transmission, Altamira Press, Walnut Creek.

ZAEHNER, R. C.

1961 Mysticism Sacred and Profane. An Inquiry into Some Varieties of Praeternatural Experience, Oxford University Press, Oxford.

\section{Kilder}

Buddhaghosa, Bhadantācariya

Visuddhimagga. Oversat af Bhikku Nanamoli (1999) [1975]: The Path of Purification, Buddhist Publication Society, Sri Lanka. 
Juan de la Cruz

Subida del Monte Carmello. Oversat af Hagen Hasselbach (1994): Bestigningen af Bjerget Karmel, Sankt Ansgars Forlag, København.

Noche Oscura del Alma. Oversat af Allison E.Peers (1953): Dark Night of the Soul. in: Allison E. Peers, ed., The Complete Works of Saint John of the Cross Vol.I, Burns Oates \& Washbourne Ltd., London.

Cántico Espirituel. Oversat af Allison E. Peers (1953): Spirituel Canticle (second redaction), in: Allison E. Peers, ed., The Complete Works of Saint John of the Cross Vol. II, Burns Oates \& Washbourne Ltd., London.

Torben Hammersholt Christensen Stud.mag. i religionsstudier Syddansk Universitet, Odense 